\title{
A high power density solid oxide fuel cell based on nano-
}

\section{structured $\mathrm{La}_{0.8} \mathrm{Sr}_{0.2} \mathrm{Cr}_{0.5} \mathrm{Fe}_{0.5} \mathrm{O}_{3-\delta}$ anode}

Tao Wei ${ }^{\text {a }}$, Xinping Zhou ${ }^{\text {a }}$, Qiang Hu ${ }^{\text {b }}$, Qingyu Gao ${ }^{\text {a* }}$, Da Han ${ }^{c}$, Xiaoli Lv ${ }^{\text {a }}$, Shaorong Wang a, c*

${ }^{a}$ College of Chemistry and Chemical Engineering, China University of Mining and Technology, Xuzhou 221116, China.

${ }^{\mathrm{b}}$ Department of Energy Conversion of Storage, Technical University of Denmark, Risø Compus, Frederiksborgvej 399, DK-4000, Roskilde, Denmark.

${ }^{c}$ CAS Key Laboratory of Materials for Energy Conversion, Shanghai Institute of Ceramics, Chinese Academy of Sciences, 1295 Dingxi Road, Shanghai 200050, China.

\begin{abstract}
Solid oxide fuel cell (SOFC) that is capable to operate on both hydrogen and methane as fuels is desired and its anode receives particular attention since it is the cell component directly converting fuels. ( $\mathrm{La}, \mathrm{Sr}) \mathrm{CrFeO}_{3-\delta}$ is regarded as a candidate anode material but its electrochemical performance has been unsatisfactory. In this study, we improved the performance of an SOFC based exclusively on a $\mathrm{La}_{0.8} \mathrm{Sr}_{0.2} \mathrm{Cr}_{0.5} \mathrm{Fe}_{0.5} \mathrm{O}_{3-\delta}$ anode by means of impregnation. At $800{ }^{\circ} \mathrm{C}$, the maximum power densities of such a cell reach $846 \mathrm{~mW} \mathrm{~cm}^{-2}$ with hydrogen as fuel, and $117 \mathrm{~mW} \mathrm{~cm}^{-2}$ when methane is fed. The anode polarization resistances are $0.06 \mathrm{ohm} \mathrm{cm}^{2}$ in hydrogen and $0.57 \mathrm{ohm} \mathrm{cm}^{2}$ in methane, estimated from impedance spectra fitting results. During a stability test of $100 \mathrm{~h}$ in hydrogen under a current loading of $850 \mathrm{~mA} \mathrm{~cm}^{-2}$, a conditioning period of ca. $50 \mathrm{~h}$ is seen during which the power density decreases moderately, and afterward the power density becomes gradually stable at around $490 \mathrm{~mW} \mathrm{~cm}^{-2}$.
\end{abstract}

${ }^{*}$ Corresponding author 1: Tel: +86 516 83591088. Fax: +86 51683591088.

E-mail address: gaoqy@cumt.edu.cn (Q.Y. Gao)

*Corresponding author 2: Tel: +86 21 52411520. Fax: +86 2152411520.

E-mail address: srwang@mail.sic.ac.cn (S.R. Wang) 
Keywords: Solid oxide fuel cell; All perovskite; Nanostructured electrodes; Impregnation.

\section{Introduction}

Solid oxide fuel cells (SOFCs) are considered as a technology that converts chemical energy into electricity with potentially higher efficiency, and have been intensively developed for decades $[1,2]$. The cermet made of nickel and yttria-stabilized zirconia (YSZ) has been the popular anode material for SOFC. However, due to the metallic nature of nickel, nickel-based cermet anode experiences some inherent drawbacks relating to sulfur poisoning and coking when using nature gas or other hydrocarbon fuels and volume instability upon redox cycling [3-5]. Thus, there is considerable interest in finding alternative anode materials.

Anode materials free of nickel and principally made of carefully selected oxides are therefore proposed [6-11]. Amid them samaria or gadolinia doped ceria [6], $\mathrm{Sr}_{2} \mathrm{MgMoO}_{6-\delta}[9,12,13]$ double perovskite, and ( $\mathrm{La}, \mathrm{Sr}) \mathrm{CrMnO}_{3-\delta}$ and $(\mathrm{La}, \mathrm{Sr}) \mathrm{CrFeO}_{3-\delta}$ perovskites $[10,11,14-21]$ receive particular attention as they provide extra advantages such as redox stability[10], sulfur and coking tolerance [6,9], and catalysis for methane conversion $[9,22]$. The perovskite $(\mathrm{La}, \mathrm{Sr}) \mathrm{CrFeO}_{3-\delta}$ is of interest to us as a candidate anode material due to its merits of good redox stability [19,22], higher conductivity and electrochemical activity than its analog $(\mathrm{La}, \mathrm{Sr}) \mathrm{CrMnO}_{3-\delta}[11,19]$, and good catalysis for methane-reforming and oxidation [22]. Importantly, the thermal expansion coefficient (TEC) of $(\mathrm{La}, \mathrm{Sr}) \mathrm{CrFeO}_{3-\delta}$ is ca. $11 \times 10^{-6} \mathrm{~K}^{-1}[19,23]$ while the TEC of $(\mathrm{La}, \mathrm{Sr}) \mathrm{CrMnO}_{3-\delta}$ is ca. $9 \times 10^{-6}$ $\mathrm{K}^{-1}[14]$. ( $\left.\mathrm{La}, \mathrm{Sr}\right) \mathrm{CrFeO}_{3-\delta}$ evidently matches better the popular electrolyte oxides such as YSZ (TEC ca. $\left.11 \times 10^{-6} \mathrm{~K}^{-1}[14,24]\right)$ and $(\mathrm{LaSr}) \mathrm{GaMgO}_{3-\delta}$ (TEC ca. $\left.12 \times 10^{-6} \mathrm{~K}^{-1}[25]\right)$. We are quite aware of the preferential importance of TEC match in our years of experience of developing SOFC stacks, and it is well known that the compatibility between interconnector and electrolyte determines the design and mechanical reliability of an SOFC stack [1]. Since we have recently developed ( $\mathrm{LaSr}) \mathrm{CrFeO}_{3-\delta}$ [23] as a possible substitute for Crofer22APU [26] or SUS 430 [27] as the interconnector material, it is then naturally for us to investigate the possibility of developing $(\mathrm{LaSr}) \mathrm{CrFeO}_{3-\delta}$ based anode for the unit cells of our SOFC stack. Though TEC match is speculated to be less important in an 
impregnated electrode structure, a better match is still desired to prevent the risk of contact loss between the backbones and the impregnated particles in course of thermal cycling of practical application.

Previous attempts have been made to use ( $\mathrm{La}, \mathrm{Sr}) \mathrm{CrFeO}_{3-\delta}$ as the anode material $[11,19,22,28,29]$, however these results are not satisfactory. The area-specific polarization resistance (ASR) of ( $\mathrm{La}, \mathrm{Sr}) \mathrm{CrFeO}_{3-\delta}$ based anode were found at least $1.2 \mathrm{ohm} \mathrm{cm}^{2}$ in $5 \%$ hydrogen atmosphere even though the temperatures were as high as $800{ }^{\circ} \mathrm{C}[11,19]$ and $850{ }^{\circ} \mathrm{C}$ [22], respectively. The corresponding maximum power density of such a full cell is only $50 \mathrm{~mW} \mathrm{~cm}^{-2}$ [11]. When methane is used as the fuel the electrochemical performance becomes even worse [22]. Though the performance of $(\mathrm{La}, \mathrm{Sr}) \mathrm{CrFeO}_{3-\delta}$ based anode is significantly improved in studies [2830], nickel is introduced again, which apparently compromises the efforts of developing an anticoking anode for hydrocarbon fuels. The stability tests of the studies lasted for less than $2.5 \mathrm{~h}$ $[28,29]$, making the stability evaluation of related $(\mathrm{La}, \mathrm{Sr}) \mathrm{CrFeO}_{3-\delta}$ anodes very difficult. In these studies the $(\mathrm{La}, \mathrm{Sr}) \mathrm{CrFeO}_{3-\delta}$ based anodes are mainly prepared by direct sintering at temperatures between $1200-1400{ }^{\circ} \mathrm{C}[11,19,22,28]$, and measures such as introduction of a barrier layer made of gadolinia doped ceria (GDC) must be taken to avoid or mitigate the reaction between ( $\mathrm{La}, \mathrm{Sr}) \mathrm{CrFeO}_{3-\delta}$ anode and the electrolyte oxides such as $(\mathrm{LaSr}) \mathrm{GaMgO}_{3-\delta}$ [19]. At these high preparation temperatures, the particle size of $(\mathrm{La}, \mathrm{Sr}) \mathrm{CrFeO}_{3-\delta}$ is supposed to grow rapidly, decreasing the length of tripe phase boundary (TPB) within the anodes [31], and therefore resulting in poor performance of full cells. Thus the aim of this study is to develop a cell that is based on an exclusively ( $\mathrm{La}, \mathrm{Sr}) \mathrm{CrFeO}_{3-\delta}$ anode, free of coking sensitive component such as nickel and have significantly improved electrochemical performance. The anode of this study will be formed at relatively low temperature of $850{ }^{\circ} \mathrm{C}$ and its stability will be preliminarily evaluated for $100 \mathrm{~h}$.

\section{Experimental}

\subsection{Preparation and Characterization of $\mathrm{La}_{0.8} \mathrm{Sr}_{0.2} \mathrm{Cr}_{0.5} \mathrm{Fe}_{0.5} \mathrm{O}_{3-\delta}$}


Based on our previous study [23], $\mathrm{La}_{0.8} \mathrm{Sr}_{0.2} \mathrm{Cr}_{0.5} \mathrm{Fe}_{0.5} \mathrm{O}_{3-\delta}$ ( $\mathrm{LSCrF}$ ) powder was synthesized by the Pechini method as the target anode oxide. Stoichiometric amounts of $\mathrm{La}\left(\mathrm{NO}_{3}\right)_{3} \cdot 6 \mathrm{H}_{2} \mathrm{O}, \mathrm{Sr}\left(\mathrm{NO}_{3}\right)_{2}$, $\mathrm{Fe}\left(\mathrm{NO}_{3}\right)_{3} \cdot 9 \mathrm{H}_{2} \mathrm{O}$ and $\mathrm{Cr}\left(\mathrm{NO}_{3}\right)_{3} \cdot 9 \mathrm{H}_{2} \mathrm{O}$ were dissolved in deionized water, citric acid was then added to the solution with the citric acid/metal-ion ratio of 1:1. After addition of excess ethylene glycol, the solution became polyester resin, which was then heated at about $200{ }^{\circ} \mathrm{C}$ and burned into powder. The powder was calcined at $850{ }^{\circ} \mathrm{C}$ for $4 \mathrm{~h}$ in air to remove all organic and carbon residues, followed by X-ray diffraction (XRD) measurements (Bruker AXS D8 Advance). The XRD measurements were all carried out at room temperature and used the $\mathrm{Cu} K \alpha$ wavelength. The scans were performed in the $2 \theta$ range $20-80^{\circ}$ at the scanning speed of $4^{\circ} \min ^{-1}$. The stability of LSCrF in reducing atmosphere was studied by heating the as-prepared $\mathrm{LSCrF}$ powder at $850{ }^{\circ} \mathrm{C}$ in wet $\mathrm{H}_{2}$ for $6 \mathrm{~h}$, and cooled down to room temperature for XRD pattern measurements. The cooling process was also carried out in $\mathrm{H}_{2}$ atmosphere. To estimate the lattice parameters, the measured XRD patterns were refined using Rietveld refinement by Jade 5 .

\subsection{Cell Fabrication}

Single cells were based on a tri-layer structure (porous/dense/porous) made of $\mathrm{La}_{0.9} \mathrm{Sr}_{0.1} \mathrm{Ga}_{0.8} \mathrm{Mg}_{0.2} \mathrm{O}_{2.85}$ (LSGM) and its fabrication details are available elsewhere [32]. The dense layer of LSGM was the electrolyte, two porous layers of a porosity of ca. $55 \%$ were backbones for impregnation of $\mathrm{LSCrF}$ and $\mathrm{LaNi}_{0.6} \mathrm{Fe}_{0.4} \mathrm{O}_{3}$ (LNF), which were followed by several times of heat treatments and finally formed the anode and cathode, respectively. The thicknesses of anode backbone, electrolyte and cathode backbone were 30,15 and $300 \mu \mathrm{m}$, respectively.

LSCrF and LNF were added into the porous electrode backbones by impregnating $1 \mathrm{M}$ aqueous nitrate solutions with the ratios of citric acid/metal-ions equaling to $1: 1$. The impregnated areas of anode and cathode were ca. 0.3 and $0.6 \mathrm{~cm}^{2}$, respectively, and the anode area of $0.3 \mathrm{~cm}^{2}$ is used for relevant electrochemical calculation including ASR, power density and current density. The impregnation area of anode was smaller to avoid short-circuiting between two electrodes. After each 
impregnation, the cell was heated at $700{ }^{\circ} \mathrm{C}$ for 20 minutes to decompose the nitrates. After 20 cycles of impregnation/decomposition, the cell was finally heated at $850{ }^{\circ} \mathrm{C}$ for $4 \mathrm{~h}$ to ensure all nitrates was completely decomposed and the target perovskite oxides were formed. The cell in total had a weight gain of $25 \%$ when all impregnation procedures completed.

\subsection{Electrochemical Measurements}

Silver ink (Shanghai research institute of synthetic resins) was painted on both electrode surfaces for collecting current and silver wires were used as voltage and current leads. Electrochemical measurements were carried out in the temperature range from 700 to $850{ }^{\circ} \mathrm{C}$. Oxygen was used as the oxidant during all electrochemical tests and the anode was fed with wet methane and hydrogen (the water vapor content was ca. 3 vol \%) at the flow rate of $100 \mathrm{~mL} / \mathrm{min}$. Electrochemical impedance spectra (EIS) were all measured at open circuit voltage (OCV) and in the frequency range from $200 \mathrm{kHz}$ to $0.1 \mathrm{~Hz}$ with the excitation potential of $20 \mathrm{mV}$. Equivalent circuit fitting of the impedance spectra were carried out by Zview 3.1. The stability test was carried out at $800{ }^{\circ} \mathrm{C}$ for $100 \mathrm{~h}$ with hydrogen as fuel. To investigate the catalytic effects of the silver paste, EIS of symmetrical LNF electrodes, with and without the silver paste as the current collector, were measured and compared. All the electrochemical tests were performed with an IM6 Electrochemical Workstation (ZAHNER, Germany). When the electrochemical tests were finished, the cell was cooled down and its cross section was examined by a Hitachi S-4800-II microscope (Japan).

\section{Results and Discussion}

\subsection{Structure and Morphology Characterizations}

Figure 1 shows XRD patterns of the as-prepared and reduced LSCrF powders. Reduction of the as-prepared $\mathrm{LSCrF}$ powder was carried out at $850{ }^{\circ} \mathrm{C}$ in wet $\mathrm{H}_{2}$ for $6 \mathrm{~h}$. Small peaks are seen in the $2 \theta$ range $20-30^{\circ}$ and they indicate the minor phase of $\mathrm{SrCrO}_{4}(\mathrm{JCPDF}$ card 73-1082) [23]. After reduction, the minor phases disappeared due to dissolution of $\mathrm{SrCrO}_{4}$ into the perovskite 
structure [23,33]. The peak density increased significantly after reduction that is also seen in other study [22], and may result from enhanced crystallization of the as-prepared LSCrF powder during the high temperature reduction. Note the LSCrF powder was synthesized at $850{ }^{\circ} \mathrm{C}$ for $4 \mathrm{~h}$ but the reduction was carried out at the same temperature for $6 \mathrm{~h}$. The patterns in Figure 1 exhibited the perovskite structures (JCPD card 24-1016), and no phase segregation was detected during reduction, indicating that $\mathrm{LSCrF}$ is stable in the reducing atmosphere of wet $\mathrm{H}_{2}$ where the $\mathrm{pO}_{2}$ is ca. $10^{-20}$ atm. Therefore LSCrF can be used as a chemically stable anode material of SOFC, in agreements with relevant studies $[11,22,23]$. Noticeably, after reduction, the peaks of the XRD pattern shift slightly to lower angles (marked by dashed lines in the two exemplary peaks), meaning slight increase of the unit cell volume. Table 1 lists the calculated lattice parameters, space groups and unit cell volumes of the as-prepared and reduced LSCrF powders. After reduction the unit cell volume of the prepared LSCrF increased from 0.05883 to $0.05949 \mathrm{~nm}^{3}$ due to the increase of ionic radii of chromium and iron, especially chromium in reducing atmosphere [19].

Figure 2(a) shows the cross section of a cell where the dense electrolyte is sandwiched between the porous anode and cathode backbones. The thicknesses of electrolyte, anode backbone and cathode backbone are ca. 15, 30 and $300 \mu \mathrm{m}$, respectively. Note the cathode backbone is only partially shown in Figure 2(a). The thinner backbone of $30 \mu \mathrm{m}$ is selected for LSCrF impregnation as the anode electrode processes are believed to contribute most to the overall cell resistance. A thinner anode is helpful to reduce the resistance of full cell. Figure 2(b)-(d) show microstructures of (b) porous LSGM backbone before impregnation, (c) anode after LSCrF impregnation, and (d) cathode after LNF impregnation. After 20 cycles of impregnation-decomposition, the backbones within the electrodes were covered by a large amount of fine particles in the size of ca. $50 \mathrm{~nm}$. These particles connected to each other and had established a percolating network. The backbones were made of LSGM that is a good ionic conductor. Impregnation of electronic conductive perovskites (LSCrF and LNF) enhanced the electronic conduction of the electrode and increased the TPB to a great extent, which was vital for the preparation of electrodes with active electrochemical 
performance. An additional advantage of preparing the $\mathrm{LSCrF}$ anode by means of impregnation is that the electrode can be produced at lower temperatures such as $850{ }^{\circ} \mathrm{C}$ where finer particle size of LSCrF (anode) and LNF (cathode) can be attained and the reaction between LSCrF with the electrolyte oxide LSGM can be effectively alleviated. Usually the LSCrF anodes are prepared at temperatures above $1200{ }^{\circ} \mathrm{C}$, say $1400{ }^{\circ} \mathrm{C}$, to ensure a coherent adherence with electrolyte $[11,19,22,28]$ that results in the relatively large particle size of $0.5-2 \mu \mathrm{m}$ [19]. On the other hand, the reaction of $\mathrm{LSCrF}$ and LSGM undergoes a rapid increase from $900{ }^{\circ} \mathrm{C}$, necessitating a sandwiched barrier layer made of CGO [19]. Thus it is evident that by means of impregnation LSCrF anode of better structure can be prepared with simplified and low cost procedures.

\subsection{Electrochemical Characterizations}

Figure 3 shows Nyquist plots of the impedance spectra measured at OCV when the cell is operated on (a) hydrogen and (b) methane as fuels, and oxygen as oxidant. The impedance spectra measured in hydrogen consist of arcs of comparable size while the low frequency arcs dominate when the cell is fed with methane. Attempts were made to resolve the individual impedance contributions, with special focus on identifying the impedance of anode electrode process(es). It must be noted that the fitting of the impedance spectra hereof is only indicative and various solutions may be valid too. The equivalent circuits with two or three (RC) combinations were tried, but none of them were able to fit well, unless the constant phase element (CPE) with an exponent around 0.6 was used to replace the capacitor $\mathrm{C}$, which, however, resulted in individual resistances of comparable dependence on fuel switch, i.e., the impedance spectra of anode cannot be roughly identified. Certainly, the impedance spectra can be fitted by more combinations of (RC) than four, but less numbers of $(\mathrm{RC})$ combinations are always favored in practice. We selected to identify the anode impedance from the measurements on full cell instead of from separated electrode tests $[19,22]$, as it is known that the impedance spectra measurement are subject to experimental details such as setup futures [41], electrodes placement and alignment [42], electrode shape [43] and 
structure homogeneity [44]. We thus prefer to retrieve electrode resistance directly on a full cell in order to reduce measurement ambiguity at most as possible. At last, a series equivalent circuit made of an inductor L1, a resistor Rs, and four combinations of resistor and capacitor connected parallelly, i.e., $(\mathrm{RnCn})(\mathrm{n}=1,2,3,4)$, is found to be able to give a fairly well fitting. Figure 4 shows examples of the fitted spectra of $800{ }^{\circ} \mathrm{C}$, (a) and (b) indicate the fitted spectra when hydrogen and methane are fuels, respectively, and (c) illustrates the employed equivalent circuit. Corresponding to the four combinations of a resistor and a capacitor connected in parallel, the impedance spectra are composed of four semicircles, from high to low frequency, numbered from A1 to A4. The measured frequencies most close to the summit frequencies of the four semicircles are marked in the spectra and the fitting results are given in Table 2, along with the overall cell polarization resistance.

When the fuel is switched from hydrogen to methane, the resistances R1, R2 and R3 have a moderate increase but the resistance $\mathrm{R} 4$ increases extraordinarily by about ten times, meaning the semicircle A4 indicates principally the electrode process(es) taking place in the anode. All resistances are temperature dependent, $\mathrm{R} 2$ and $\mathrm{R} 4$ are more noticeably affected by temperature. The ohmic resistance Rs is also seen to have an obvious increase when the fuel was changed from hydrogen to methane. That is assumed to be caused by morphology change of the silver pasted used in this study for current collection. Silver particles are known to undergo fragmentation and recrystallization at elevated temperatures, i.e. above $700{ }^{\circ} \mathrm{C}$ when they are in contact with hydrocarbons [34,35]. Fragmentation and recrystallization might happen to the silver paste during our test, especially when methane was fed to the cell. The fragmentation results in the increased resistance for current conduction and is finally reflected by increase in the ohmic resistance.

To investigate the possible catalysis effects of the silver paste, impedance spectra of symmetric LNF electrodes, with and without silver paste, were measured in air. The impedance spectra have a rather simple appearance of a slightly compressed semicircle, with two definite intercepts of highand low- frequency. For the reason of simplicity, the spectra are not shown here but only listing the ohmic and polarization resistances in Table 3. Clearly, the silver paste, in general, imposes effects 
on reducing the ohmic resistance instead of decreasing the polarization resistance. This is of no surprise as many typical oxides used on present solid oxide cells are comparable or even better catalysts relative to the normal metallic catalysts such as platinum and silver $[7,22,36,37]$. Therefore when silver co-exists with oxide(s) of comparable or better catalysis capability, its effects on reducing electrode polarization resistance may not be prominent.

Understanding impedance spectra has been a challenge to researchers of solid oxide cells. Though a variety of deconvolution methods have been proposed such as differential impedance analysis (DIA), distributions of relaxation times (DRT), and analysis of difference in impedance spectra (ADIS) [38-40], they are subject to respective limitations and cannot give results without ambiguity. The primary aim of impedance spectra deconvolution of this study is to identity the polarization resistance of LSCrF anode that, to a large extent, can be estimated from the semicircle A4. At $800{ }^{\circ} \mathrm{C}$, R4 is $0.06 \mathrm{ohm} \mathrm{cm}^{2}$ in hydrogen and $0.57 \mathrm{ohm} \mathrm{cm}^{2}$ in methane, both are less than $4.6 \mathrm{ohm} \mathrm{cm}{ }^{2}$ [11], $1.79 \mathrm{ohm} \mathrm{cm}^{2}$ [22], $1.2 \mathrm{ohm} \mathrm{cm}^{2}$ [19] of the (La,Sr) $\mathrm{CrFeO}_{3-\delta}$ anodes of other studies, even though they were measured in $5 \%$ hydrogen atmosphere. Since the polarization resistances of full cell are 0.18 in hydrogen and $0.75 \mathrm{ohm} \mathrm{cm}^{2}$ in methane, respectively, both of them are lower than the anode polarization resistances given in the relevant references $[11,19,22]$, the LSCrF anode prepared in this study definitely has lower polarization resistance.

Figure 5 shows the I-V and I-P plots of the cell. In hydrogen, the maximum power densities are 524, 756 and $846 \mathrm{~mW} \mathrm{~cm}^{-2}$ at 700, 750 and $800{ }^{\circ} \mathrm{C}$, respectively. When the cell is fed with wet methane, the maximum power densities are $117 \mathrm{~mW} \mathrm{~cm}^{-2}$ at $800{ }^{\circ} \mathrm{C}$ and $245 \mathrm{~mW} \mathrm{~cm}^{-2}$ at $850{ }^{\circ} \mathrm{C}$ respectively. These maximum power densities are significantly improved than that in reference [11], which is based on the exclusively ( $\mathrm{La}, \mathrm{Sr}) \mathrm{CrFeO}_{3-\delta}$ anode, $\mathrm{LSGM}$ electrolyte and $\mathrm{Ba}_{0.5} \mathrm{Sr}_{0.5} \mathrm{CoFeO}_{3-\delta}$ cathode.

$\mathrm{Sr}_{2} \mathrm{Fe}_{1.5} \mathrm{Mo}_{0.5} \mathrm{O}_{6-\delta}$ [45] and $\mathrm{Sr}_{2} \mathrm{MgMoO}_{6-\delta}$ [9] are recently published novel anode materials, especially the latter $\mathrm{Sr}_{2} \mathrm{MgMoO}_{6-\delta}$ showed impressive performance [9]. The maximum power densities of the cell based on $\mathrm{Sr}_{2} \mathrm{Fe}_{1.5} \mathrm{Mo}_{0.5} \mathrm{O}_{6-\delta}$ anode are 835 and $230 \mathrm{~mW} \mathrm{~cm}{ }^{-2}$ at $900{ }^{\circ} \mathrm{C}$, with 
hydrogen and wet methane as the fuels [45], slightly lower than the corresponding results that were measured on our cell at 800 and $850{ }^{\circ} \mathrm{C}$, respectively. Our cell is believed to have higher power density under the same conditions. The maximum power densities of the cell based on $\mathrm{Sr}_{2} \mathrm{MgMoO}_{6-}$ $\delta$ anode were reported to be $838 \mathrm{~mW} \mathrm{~cm}^{-2}$ in hydrogen and $338 \mathrm{~mW} \mathrm{~cm}^{-2}$ in wet methane at $800{ }^{\circ} \mathrm{C}$, the maximum power density of our cell is higher in hydrogen but lower in wet methane.

\subsection{Stability Test}

Figure 6 shows the power density variation during a stability test of $100 \mathrm{~h}$ with a constant current load of $850 \mathrm{~mW} \mathrm{~cm}^{-2}$ at $800{ }^{\circ} \mathrm{C}$. A conditioning process existed in the initial $50 \mathrm{~h}$ during which the power density decreased moderately, and afterward the power density gradually became stable at around $490 \mathrm{~mW} \mathrm{~cm}^{-2}$. That may be caused by the morphology change of the silver current collector. At high temperature such as $800{ }^{\circ} \mathrm{C}$ the increase of silver grain size is very rapid inducing a lowering of current collection.

Figure 7 shows the microstructures of (a) anode and (b) cathode after the stability test. The impregnated nano particles within the electrodes grow noticeably if comparison is made between the corresponding images of Figure 2 and 8. Compared with the untested electrodes shown in Figure 2 (c) and (d), the size of impregnated LSCrF and LNF particles grew from ca. 50 to $100 \mathrm{~nm}$. It is worthwhile noting that the $(\mathrm{La}, \mathrm{Sr}) \mathrm{CrFeO}_{3-\delta}$ grain size in the range of $0.5-2 \mu \mathrm{m}$ were found not to significantly change in a period of $150 \mathrm{~h}$ [19], meaning the gain size increase of this study might be caused by the relatively large current loading, e.g. $850 \mathrm{~mW} \mathrm{~cm}^{-2}$. Alternatively, there might be a threshold grain size such as $100 \mathrm{~nm}$ below which the impregnated LSCrF and LNF particles grow at elevated temperatures. The growth of electrode particles decreases the TPB and may partially account for the conditioning period observed in the test of Figure 6.

\section{Conclusions}

LSCrF is chemically stable in reducing atmosphere where the $\mathrm{pO}_{2}$ is ca. $10^{-20}$ atm and can be 
used in an SOFC as the anode for converting methane and hydrogen directly. By impregnation, the performance, in terms of power density and anode polarization resistance, of a cell based exclusively on LSCrF anode is significantly improved, and is even better than the cell based on $\mathrm{Sr}_{2} \mathrm{Fe}_{1.5} \mathrm{Mo}_{0.5} \mathrm{O}_{6-\delta}$ anode. During a stability test of $100 \mathrm{~h}$, a conditioning period of ca. $50 \mathrm{~h}$ is seen during which the power density decreases moderately, but afterward the power density becomes gradually stable.

\section{Acknowledgments}

This work was supported in part by Grants from the National Natural Science Foundation of China(51221462), Grant from the Natural Science foundation of Jiangsu Province (BK2011006), Fundamental Research Funds for the Central Universities (No. 2013XK05), Youth Science and Technology Fund of China University of Mining and Technology (JGH110871) and Jiangsu

Ordinary University Graduate Innovative Research Programs. Dr. Nguyen Minh (Center for Energy Research, University of California at San Diego) and Dr. D.W. Ni (Department of Energy Conversion and Storage, Technical University of Denmark) are appreciated for inspiring discussion.

\section{References:}

[1] H. Yokokawa, N. Sakai, T. Horita, K. Yamaji, Fuel Cells 1(2) (2001) 117.

[2] B.C.H. Steele, Solid State Ionics 134 (2000) 3.

[3] Y. Matsuzaki, I. Yasuda, Solid State Ionics 132 (2000) 261.

[4] B.C.H. Steele, I. Kelly, H. Middleton, R. Rudkin, Solid State Ionics 28 (1988) 1547.

[5] H. Kim, S. Park, J.M. Vohs, R.J. Gorte, J. Electrochem. Soc. 148 (2001) A693.

[6] E. Perry Murray, T. Tsai, S.A. Barnett, Nature 400 (1999) 649.

[7] A. Atkinson, S. Barnett, R.J. Gorte, Nat. Mater. 3 (2004) 17.

[8] P.I. Cowin, C.T.G. Petit, R. Lan, J.T.S. Irvine, S.W. Tao, Adv. Energy Mater. 1 (2011) 314.

[9] Y.H. Huang, R.I. Dass, Z.L. Xing, J. B. Goodenough, Science 312 (2006) 254. 
[10] S.W. Tao, J.T.S. Irvine, Nat. Mater. 2 (2003) 320.

[11] J. Peña-Martinez, D. Marrero-López, D. Pérez-Coll, J.C. Ruiz-Morales, P. Núñez. Electrochim. Acta 52 (2007) 2950.

[12] Y.H. Huang, R.I. Dass, J.C. Denyszyn, J.B. Goodenough, J. Electrochem. Soc. 153 (2006) A1266.

[13] C. Bernuy-Lopez, M. Allix, C.A. Bridges, J.B. Claridge, M.J. Rosseinsky, Chem. Mater. 19 (2007) 1035 .

[14] S. W. Tao, J. T. S. Irvine, J. Electrochem. Soc. 151 (2004) A252.

[15] S.W. Tao, J.T.S. Irvine, J.A. Kilner, Adv. Mater. 17 (2005) 1734.

[16] D.M. Bastidas, S.W. Tao, J.T.S. Irvine, J. Mater. Chem. 16 (2006) 1603.

[17] M. Oishi, K. Yashiro, K. Sato, J. Mizusaki, T. Kawada, J. Solid State Chem. 181 (2008) 3177.

[18] J.M. Haag, B.D. Madsen, S.A. Barnett, K.R. Poeppelmeier, Electrochem. Solid-State. Lett. 11 (2008) B51.

[19] M.F. Lü, E.V. Tsipis, J.C. Waerenborgh, A.A. Yaremchenko, V.A. Kolotygin, S. Bredikhin, V.V. Kharton, J. Power Sources 206 (2012) 59.

[20] J.C. Ruiz-Morales, J. Canales-Vázquez, J. Peña-Martínez, D. Marrero-López, P. Núñez, Electrochim. Acta 52 (2006) 278.

[21] V.V. Kharton, E.V. Tsipis, I.P. Marozau, A.P. Viskup, J.R. Frade, J.T.S. Irvine, Solid State Ionics, 178 (2007) 101.

[22] S.W. Tao, J.T.S. Irvine, Chem. Mater. 16 (2004) 4116.

[23] T. Wei, X.J. Liu, C. Yuan, Q.Y. Gao, X.S. Xin, S.R. Wang, J. Power Sources 250 (2014) 152.

[24] H. Hayashi, T. Saitou, N. Maruyama, H. Inaba, K. Kawamura, M. Mori, Solid State Ionics $176(2005) 613$.

[25] K. Huang, M. Feng, J.B. Goodenough, C. Milliken, J. Electrochem. Soc. 144 (1997) 3620.

[26] P. Leone, A. Lanzini, B. Delhomme, G.A. Ortigoza-Villalba, M. Santarelli, F. Smeacetto, M. 
Salvo, M. Ferraris, J. Fuel Cell Sci. Technol. 8 (2011) 031009-1.

[27] T. Brylewski, M. Nanko, T. Maruyama, K. Przybylski, Solid State Ionics 143 (2001) 131.

[28] X.B. Zhu, Z. Lü, B. Wei, K.F. Chen, M.L. Liu, X.Q. Huang, W.H. Su, Electrochem. SolidState Lett. 12 (2009) B161.

[29] X.B. Zhu, Z. Lü, B. Wei, Y.H. Zhang, X.Q. Huang, W.H. Su, Electrochem. Solid-State Lett. 13(8) (2010) B91.

[30] X.B. Zhu, Z. Lü, B. Wei, Y.H. Zhang, X.Q. Huang, W.H. Su, Int. J. Hydrogen Energy 35 (2010) 6897.

[31] S.P. Jiang, Mater. Sci. Eng. A 418 (2006) 199.

[32] D. Han , X.J. Liu, F.R. Zeng, J.Q. Qian, T.Z. Wu, Z.L. Zhan, A micro-nano porous oxide hybrid for efficient oxygen reduction in reduced-temperature solid oxide fuel cells. Sci. Rep. 2, 462; DOI:10.1038/srep00462 (2012)..

[33] L.A. Chick, J. Liu, J.W. Stevenson, T.R. Armstrong, D.E. McCready, G.D. Maupin, G.W. Coffey, C.A. Coyle, J. Am. Ceram. Soc. 80 (1997) 2109.

[34] A. Nagy, G. Mestl, Applied Catalysis A: General 188 (1999) 337.

[35] M.X. Yang, P.W. Jacobs, C. Yoon, L. Muray, E. Anderson, D. Attwood, G.A. Somorjai, Catalysis Letters 45 (1997) 5.

[36] M. Mogensen, ECS Transactions 45 (2012) 3.

[37] Q. Hu, T. Jacobsen, K.V. Hansen, M. Mogensen, J. Electrochem. Soc. 159 (2012) B811.

[38] H. Schichlein, A.C. Muller, M. Voigts, A. Krugel, E. Ivers-Tiffee, J. Appl. Electrochem. 32 (2002) 875 .

[39] S.H. Jensen, A. Hauch, P.V. Hendriksen, M. Mogensen, N. Bonanos, T. Jacobsen, J. Electrochem. Soc. 154 (2007) B1325.

[40] W. Vielstich, H. Yokokawa, H.A. Gasteiger, Chapter 53 of Handbook of Fuel Cells, John Wiley \& Sons, Chichester (2009) 1-13.

[41] T. Jacobsen, P.V. Hendriksen, S. Koch, Electrochimi. Acta 53 (2007) 7500. 
[42] S.B. Adler, J. Electrochem. Soc. 149 (2002) E166.

[43] T. Jacobsen, K. West, Electrochimi. Acta 40 (1995) 255.

[44] M.E. Orazem, B. Tribollet, Electrochemical Impedance Spectroscopy, John Wiley \& Sons, Inc., New Jersey (2008).

[45] Q. Liu, X.H. Dong, G. Xiao, F. Zhao, F.L. Chen, Adv. Mater. 22 (2010) 5478. 


\section{Tables and Figures:}

Table 1. Room temperature lattice parameters, space groups and unit cell volumes of the asprepared and reduced $\mathrm{La}_{0.8} \mathrm{Sr}_{0.2} \mathrm{Cr}_{0.5} \mathrm{Fe}_{0.5} \mathrm{O}_{3-\delta}$ powders.

\begin{tabular}{|c|c|c|c|c|c|}
\hline & \multicolumn{3}{|c|}{ Lattice parameters } & \multirow[t]{2}{*}{ Space group } & \multirow[t]{2}{*}{$V\left(n m^{3}\right)$} \\
\hline & $\mathrm{a}(\mathrm{nm})$ & $\mathrm{b}(\mathrm{nm})$ & $\mathrm{c}(\mathrm{nm})$ & & \\
\hline $\begin{array}{c}\mathrm{La}_{0.8} \mathrm{Sr}_{0.2} \mathrm{Cr}_{0.5} \mathrm{Fe}_{0.5} \mathrm{O}_{3-\delta} \\
\text { (as-prepared) }\end{array}$ & 0.548483 & 0.55136 & 0.7781 & $R \overline{3} C$ & 0.05883 \\
\hline $\begin{array}{l}\mathrm{La}_{0.8} \mathrm{Sr}_{0.2} \mathrm{Cr}_{0.5} \mathrm{Fe}_{0.5} \mathrm{O}_{3-\delta} \\
\text { (after reduction) }\end{array}$ & 0.551699 & 0.550681 & 0.783231 & $R \overline{3} C$ & 0.05949 \\
\hline
\end{tabular}

Table 2. Fitting results of the impedance spectra. The equivalent circuit is shown in Figure 4(c), and oxygen is the oxidant. The resistance, inductance and capacitance are in units of ohm $\mathrm{cm}^{2}, \mu \mathrm{H} \mathrm{cm}{ }^{2}$ and $\mathrm{mF} \mathrm{cm}^{-2}$, respectively.

\begin{tabular}{|c|c|c|c|c|c|c|c|c|c|}
\hline \multicolumn{6}{|c|}{$\mathrm{H}_{2}$} & \multicolumn{4}{|c|}{$\mathrm{CH}_{4}$} \\
\hline \multicolumn{2}{|c|}{$700{ }^{\circ} \mathrm{C}$} & \multicolumn{2}{|c|}{$750{ }^{\circ} \mathrm{C}$} & \multicolumn{2}{|c|}{$800^{\circ} \mathrm{C}$} & \multicolumn{2}{|c|}{$800{ }^{\circ} \mathrm{C}$} & \multicolumn{2}{|c|}{$850^{\circ} \mathrm{C}$} \\
\hline & 0.16 & L1 & 0.15 & & 0.13 & L1 & 0.14 & L1 & 0.15 \\
\hline Rs & 0.23 & Rs & 0.12 & Rs & 0.09 & Rs & 0.19 & Rs & 0.17 \\
\hline $\mathrm{R} 1$ & 0.06 & $\mathrm{R} 1$ & 0.04 & $\mathrm{R} 1$ & 0.03 & $\mathrm{R} 1$ & 0.05 & $\mathrm{R} 1$ & 0.04 \\
\hline $\mathrm{C} 1$ & 0.49 & $\mathrm{C} 1$ & 1.48 & $\mathrm{C} 1$ & 2.48 & $\mathrm{C} 1$ & 0.85 & $\mathrm{C} 1$ & 1.13 \\
\hline $\mathrm{R} 2$ & 0.10 & $\mathrm{R} 2$ & 0.05 & $\mathrm{R} 2$ & 0.02 & $\mathrm{R} 2$ & 0.05 & $\mathrm{R} 2$ & 0.03 \\
\hline $\mathrm{C} 2$ & 2 & $\mathrm{C} 2$ & 6 & $\mathrm{C} 2$ & 25 & $\mathrm{C} 2$ & 9 & $\mathrm{C} 2$ & 17 \\
\hline R3 & 0.09 & R3 & 0.05 & R3 & 0.06 & R3 & 0.08 & R3 & 0.10 \\
\hline C3 & 11 & $\mathrm{C} 3$ & 71 & $\mathrm{C} 3$ & 109 & $\mathrm{C} 3$ & 136 & $\mathrm{C} 3$ & 107 \\
\hline $\mathrm{R} 4$ & 0.19 & $\mathrm{R} 4$ & 0.12 & $\mathrm{R} 4$ & 0.06 & $\mathrm{R} 4$ & 0.57 & $\mathrm{R} 4$ & 0.27 \\
\hline $\mathrm{C} 4$ & 68 & $\mathrm{C} 4$ & 131 & $\mathrm{C} 4$ & 382 & $\mathrm{C} 4$ & 92 & $\mathrm{C} 4$ & 140 \\
\hline $\mathrm{Rp}$ & 0.44 & $\mathrm{Rp}$ & 0.25 & $\mathrm{Rp}$ & 0.18 & $\mathrm{Rp}$ & 0.75 & $\mathrm{Rp}$ & 0.44 \\
\hline
\end{tabular}


Table 3. Ohmic resistance Rs (unit: $\mathrm{ohm} \mathrm{cm}^{2}$ ) and polarization resistance Rp (unit: ohm $\mathrm{cm}^{2}$ ) of the symmetric LNF electrodes, with and without Ag paste, as the current collector. Note the LNF electrodes are impregnated into the LSGM backbones and the tests are in air.

\begin{tabular}{|c|c|c|c|c|c|c|c|c|}
\hline & \multicolumn{2}{|c|}{$700^{\circ} \mathrm{C}$} & \multicolumn{2}{|c|}{$750{ }^{\circ} \mathrm{C}$} & \multicolumn{2}{|c|}{$800{ }^{\circ} \mathrm{C}$} & \multicolumn{2}{|c|}{$850{ }^{\circ} \mathrm{C}$} \\
\hline & With & Without & With & Without & With & Without & With & Without \\
\hline & $\mathrm{Ag}$ & $\mathrm{Ag}$ & $\mathrm{Ag}$ & $\mathrm{Ag}$ & $\mathrm{Ag}$ & $\mathrm{Ag}$ & $\mathrm{Ag}$ & $\mathrm{Ag}$ \\
\hline Rs & 0.07 & 0.20 & 0.06 & 0.18 & 0.06 & 0.20 & 0.05 & 0.27 \\
\hline $\mathrm{Rp}$ & 0.12 & 0.14 & 0.07 & 0.05 & 0.03 & 0.02 & 0.02 & 0.02 \\
\hline
\end{tabular}




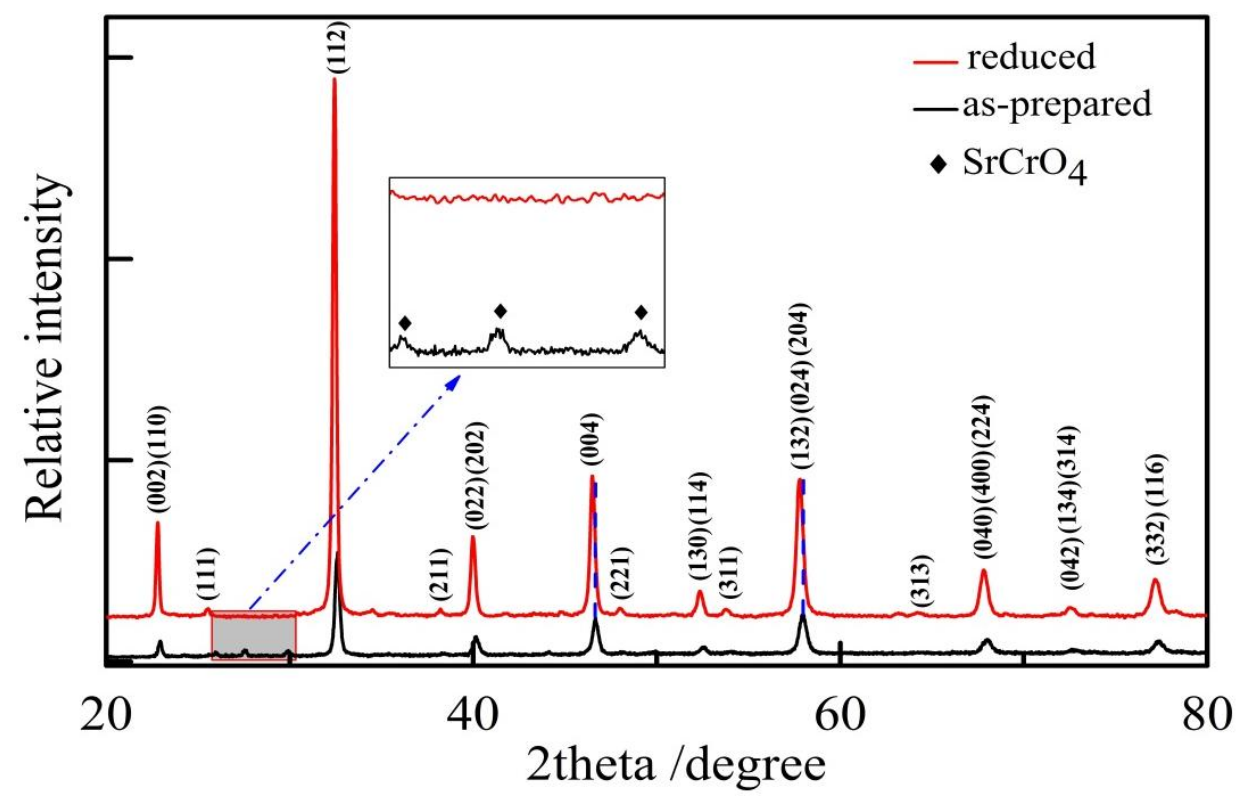

Figure 1. XRD patterns of the as-prepared and reduced $\mathrm{La}_{0.8} \mathrm{Sr}_{0.2} \mathrm{Cr}_{0.5} \mathrm{Fe}_{0.5} \mathrm{O}_{3-\delta}$ powders. The reduction was carried out at $850{ }^{\circ} \mathrm{C}$ in wet hydrogen for $6 \mathrm{~h}$. No phase segregation is detected during the reduction test.
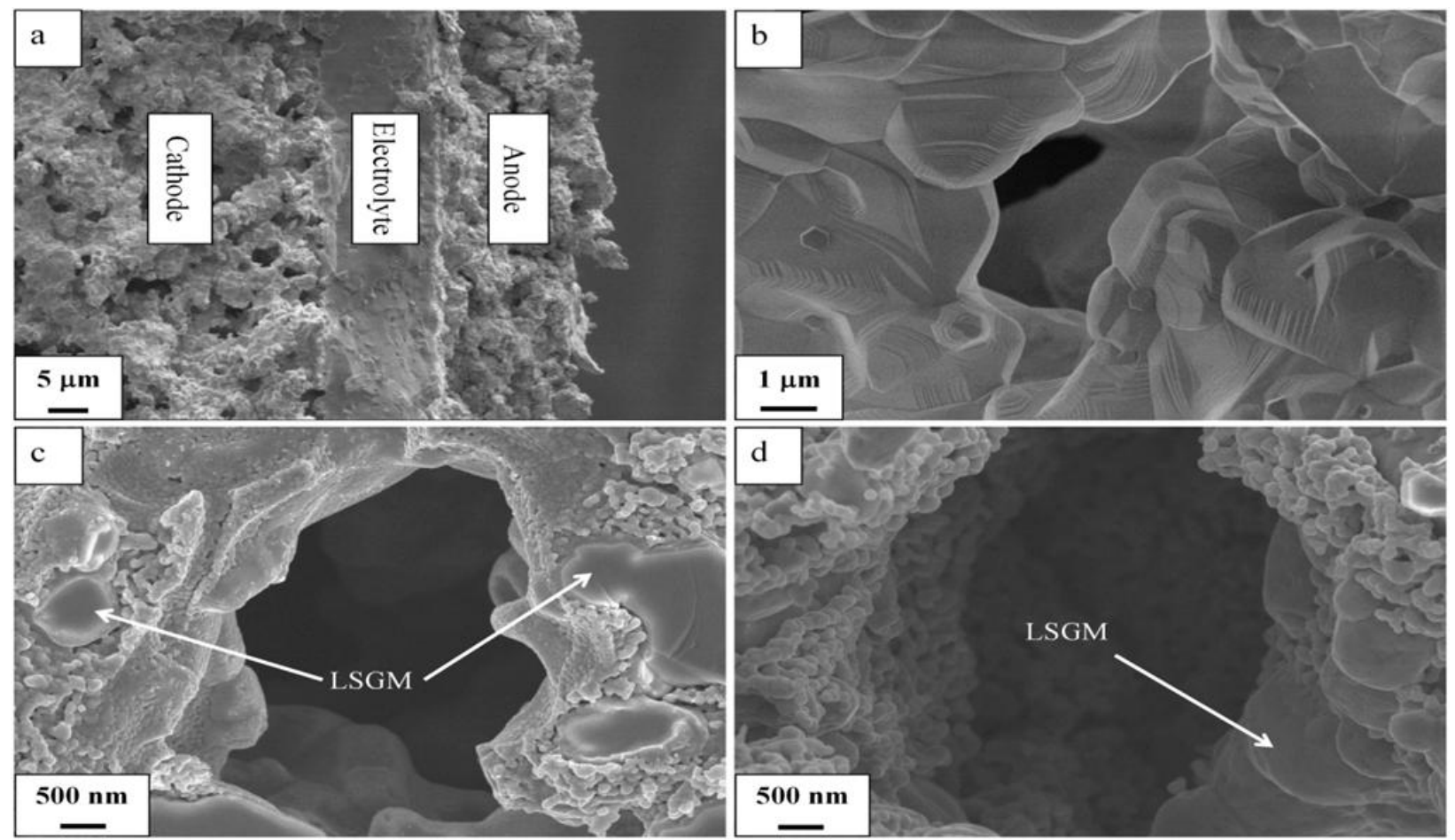

Figure 2. (a) cross section of a cell. Note the cathode backbone of a thickness of $300 \mu \mathrm{m}$ is not completely shown. (b) porous LSGM electrode backbone before impregnation, (c) anode after LSCrF impregnation, (d) cathode after LNF impregnation. A large amount of particles of ca. $50 \mathrm{~nm}$ were formed after 20 cycles of impregnation/decomposition. These particles are LSCrF in anode and LNF in cathode. 

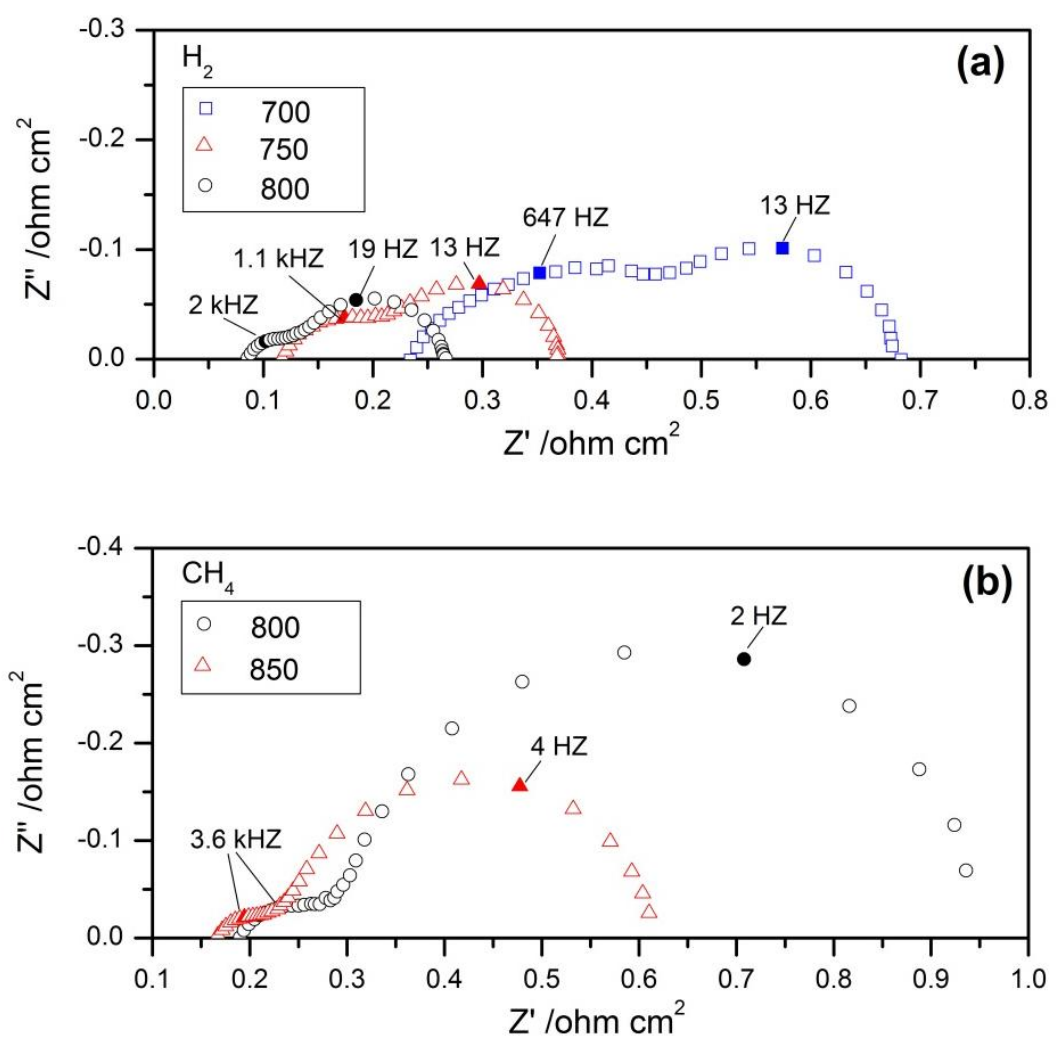

Figure 3. Nyquist plots of the impedance spectra measured at OCV when the cell was operated on (a) hydrogen and (b) methane as fuels, and oxygen as oxidant. The impedance spectra measured in hydrogen consist of arcs of comparable size while the low frequency arcs dominate when the cell is fed with methane. 

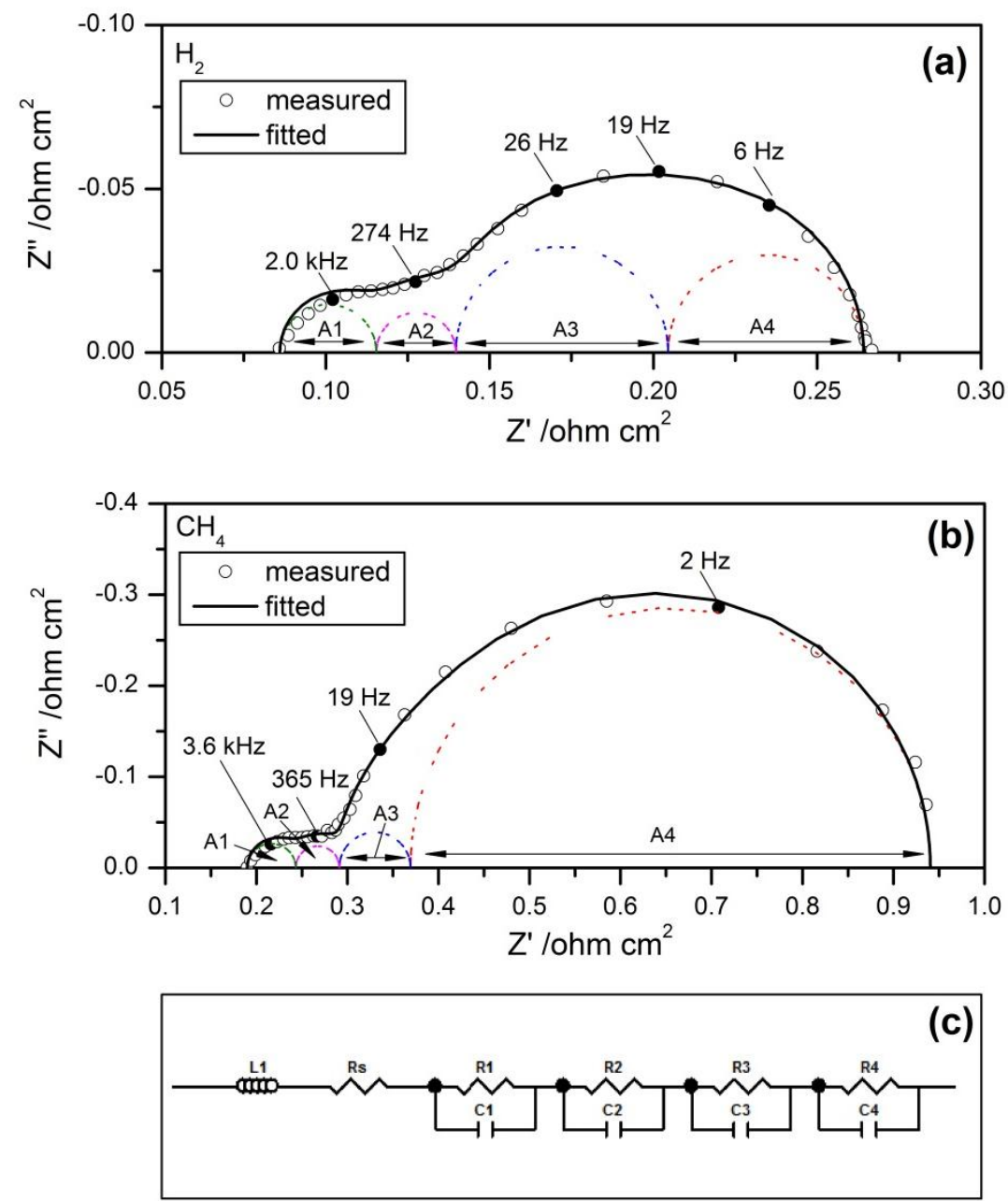

Figure 4. Fitting examples of impedance spectra measured at $800{ }^{\circ} \mathrm{C}$, (a) in hydrogen, (b) in methane and (c) the used equivalent circuit. 


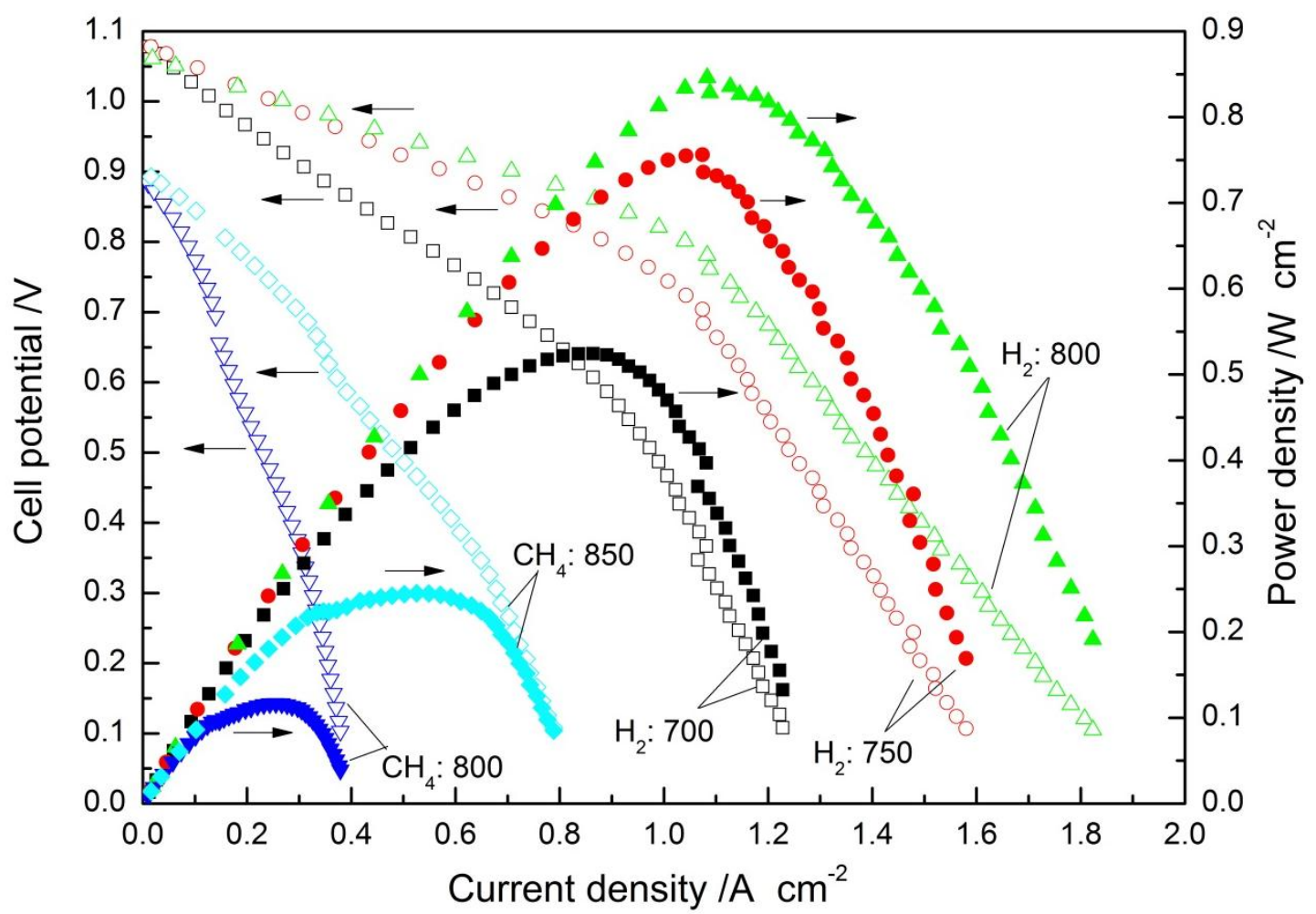

Figure 5. I-V and I-P curves of the cells with oxygen as the oxidant. Cell voltages are indicated by open symbols and power densities by filled symbols. The maximum power densities are 524, 756 and $846 \mathrm{~mW} \mathrm{~cm}^{-2}$ at 700,750 and $800{ }^{\circ} \mathrm{C}$, respectively, when the cell was fed with hydrogen. In wet methane, the maximum power densities are 117 and $245 \mathrm{~mW} \mathrm{~cm}^{-2}$ at 800 and $850{ }^{\circ} \mathrm{C}$.

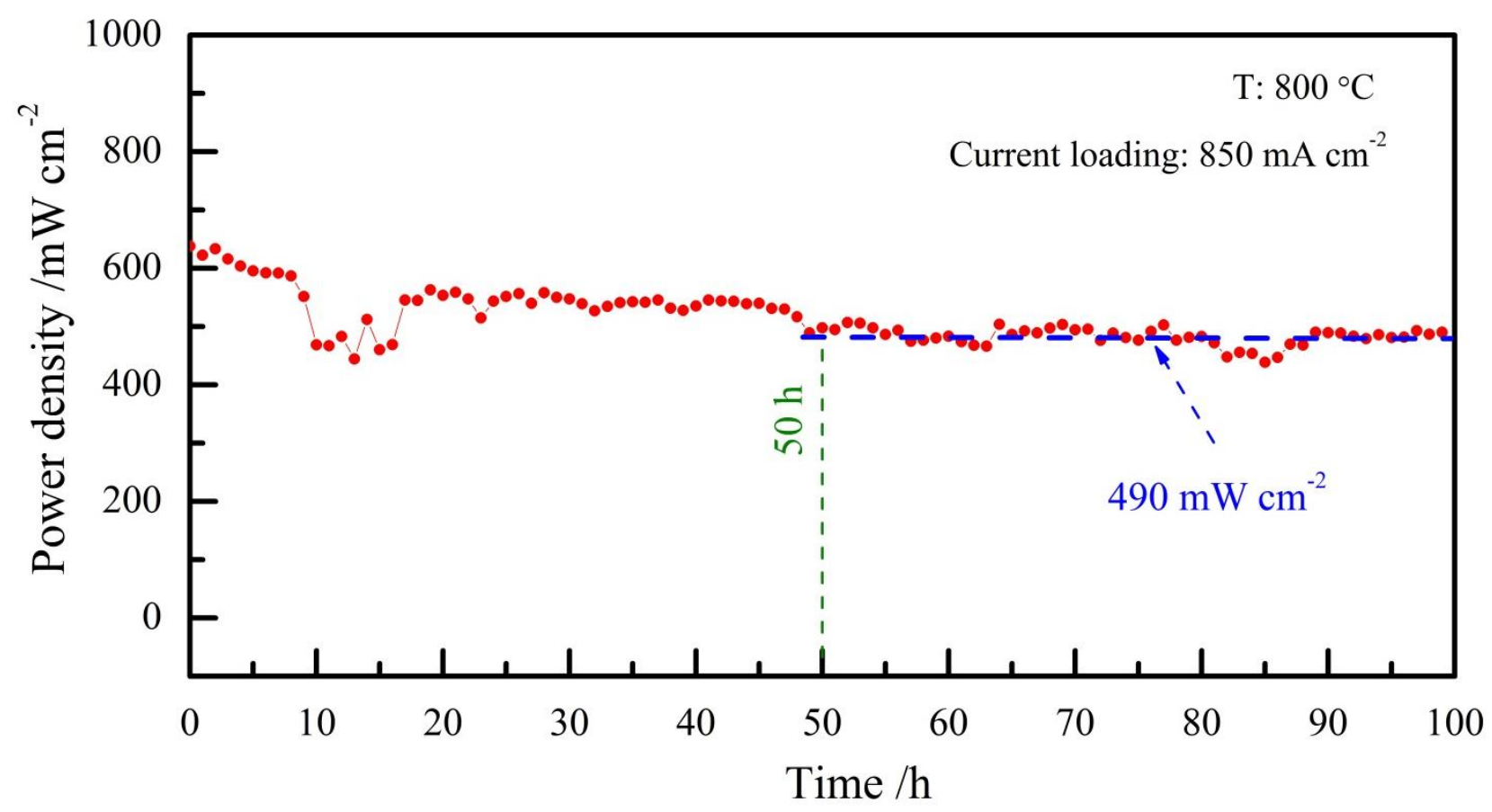

Figure 6. Stability test at $800{ }^{\circ} \mathrm{C}$ with a constant current load of $850 \mathrm{~mA} \mathrm{~cm}{ }^{-2}$. A conditioning process exists in the initial $50 \mathrm{~h}$ during which the power density decreases moderately, and afterward the power density becomes gradually stable at around $490 \mathrm{~mW} \mathrm{~cm}$. 

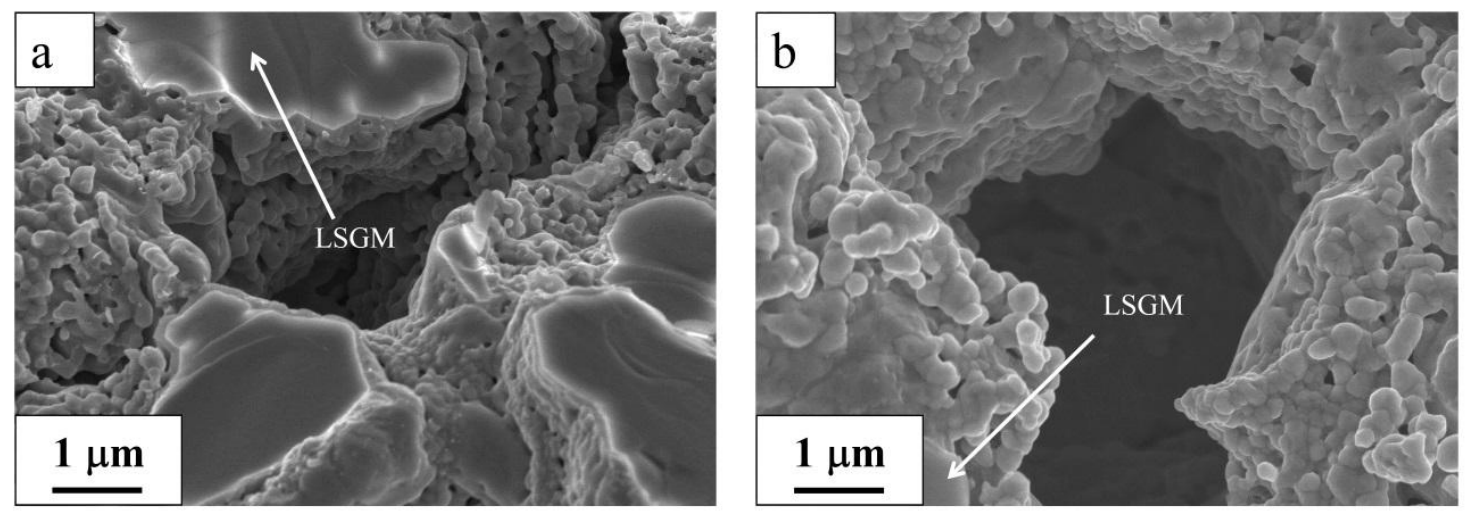

Figure 7. Microstructure of electrodes after a stability test of $100 \mathrm{~h}$. (a) anode (b) cathode. Growth of impregnated nano LSCrF (anode) and LNF (cathode) particles are seen after the stability test. 


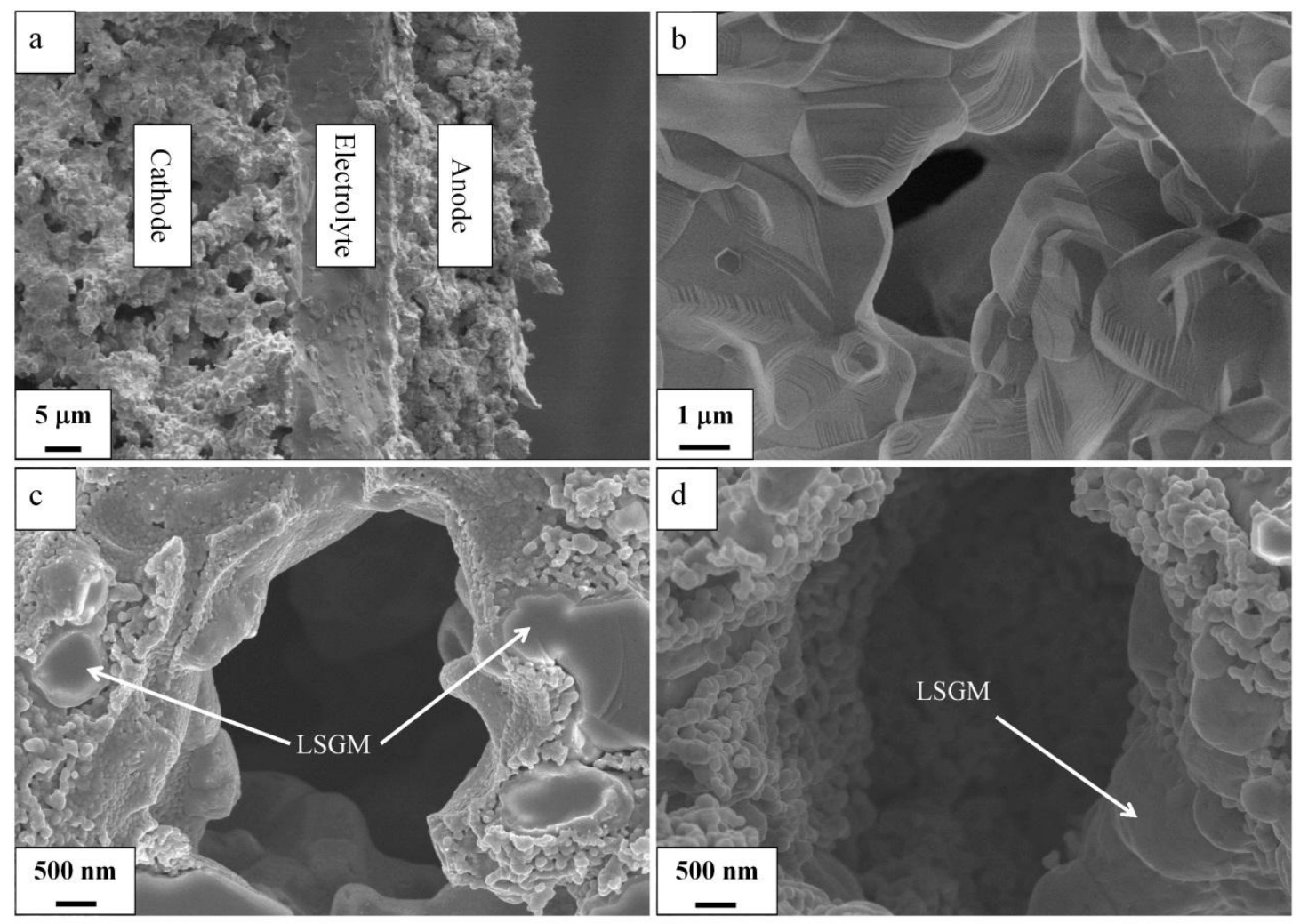

